\title{
COMBINING ABILITIES OF GROWTHTRAITS AMONG PURE AND CROSSBRED MEAT TYPE CHICKENS
}

\author{
POSIBILIDADES DE COMBINACIÓN DE LAS CARACTERÍSTICAS DE CRECIMIENTO \\ ENTRE POLLOS PARA CARNE PUROS Y CRUZADOS
}

\author{
Adebambo, A.O. ${ }^{1 *}$, Ikeobi, C.O.N. ${ }^{1}$, Ozoje, M.O. ${ }^{1}$, Oduguwa, O.O. ${ }^{1}$ \\ and Adebambo Olufunmilayo, A. ${ }^{1}$
}

\begin{abstract}
${ }^{1}$ Department of Animal Breeding and Genetics. College of Animal Science and Livestock Production. University of Agriculture. Abeokuta. Nigeria. *tumininuadebambo@yahoo.com
\end{abstract}

\section{AdDitionAL KEYWORDS}

Poultry breeds. Indigenous poultry. Improvement.

\section{SUMMARY}

Five thousand one hundred and nineteen chicks were obtained from a diallel combination of four breeds of chickens; (Anak Titan (A), Alpha (B), Giriraja (G) and Normal indigenous (N) chickens) in a broiler improvement program. The chicks were reared to 12 weeks in which data on weekly body weight (BW), breast girth (BG) and tibia length (TL) were recorded. Sire and dam genotype significantly $(p<0.05)$ affected all traits. Anak Titan cocks and hens performed best in body weight (BW) with values ranging from $38.45 \pm 0.74 \mathrm{~g}$ and $40.21 \pm$ $0.66 \mathrm{~g}$ at day old to $1135.93 \pm 35.67 \mathrm{~g}$ and 953.38 $\pm 35.38 \mathrm{~g}$ at week 12 respectively. Normal and Alpha improved indigenous performed better in linear body parameters. Results of diallel analysis to test for general and specific combining abilities of breeds on traits showed that additive genetic effects were important in determining BW and dominance effects were important for BG, while both effects were important in determining TL. This indicates that selection, crossbreeding and combination of both are tools needed to improve BW, BG and TL, respectively. Anak Titan had the best general combining ability (GCA) of $19.49 \pm$ $0.42,288.54 \pm 7.52,458.78 \pm 12.15$ and $769.30 \pm$ 4.80 for BW at weeks $1,4,8$ and 12 , respectively and therefore recommended as a good breed for BW in the improvement program. GB crosses had the best SCA for BG and TL of $7.43 \pm 0.11,8.21$ $\pm 0.16,11.82 \pm 0.22,5.90 \pm 0.29 ; 8.50 \pm 0.10,9.68$ $\pm 0.10,7.92 \pm 0.34,0.86 \pm 0.30$ at weeks $1,4,8$ and 12 respectively. It is recommended that an impro-

\section{Palabras clave adicionales}

Razas de gallinas. Gallinas autóctonas. Mejora. vement process that involves all the breeds should be adapted using reciprocal recurrent selection or modifications of it.

\section{RESUMEN}

Cinco mil ciento diecinueve pollos fueron obtenidos, en un programa de mejora de pollos de engorde, a partir de una combinación dialélica de cuatro razas: Anak Titan (A), Alpha (B), Giriraja (G) y Normal indígena (N). Los pollos fueron criados a 12 semanas en las que se registraron los datos sobre peso corporal por semana (BW), circunferencia del pecho (BG) y longitud de la tibia (TL). El genotipo de machos y hembras afectó significativamente $(p<0,05)$ a todos los caracteres. Los gallos y las gallinas Anak Titan mostraron el mejor comportamiento en peso corporal (BW) con valores que van desde $38,45 \pm 0,74 \mathrm{~g}$ a 40,21 $\pm 0,66 \mathrm{~g}$ al día de edad hasta $1135,93 \pm 35,67 \mathrm{~g}$ y $953,38 \pm 35,38 \mathrm{~g}$ en la semana 12 , respectivamente. Las razas indígenas mejoradas Normal y Alpha obtuvieron mejores resultados en los parámetros lineales del cuerpo. Los resultados del análisis dialélico para probar las capacidad general y específica de combinación de las razas en los caracteres, mostraron que los efectos genéticos aditivos fueron importantes en la determinación BW y los efectos de dominancia fueron importantes para BG, mientras que ambos efectos son importantes en la determinación de TL. Esto indica que la selección, el mestizaje y la combinación de 
ambos son las herramientas necesarias para mejorar la PN, BG y TL, respectivamente. Anak y Titan han mostrado la mejor aptitud combinatoria general (GCA) de 19,49 $\pm 0,42 ; 7,52 \pm 288,54$; $458,78 \pm 12,15$ y $769,30 \pm 4,80$ para BW en las semanas 1, 4, 8 y 12, respectivamente, por lo que se recomienda como una buena raza para el programa de mejora de BW. Los cruces GB presentaron la mejor SCA para BG y TL de 7,43 $\pm 0,11$; $8,21 \pm 0,16 ; 11,82 \pm 0,22 ; 5,90 \pm 0,29 ; 8,50 \pm 0,10$; $9,68 \pm 0,10 ; 7,92 \pm 0,34$ y $0,86 \pm 0,30$ en las semanas $1,4,8$ y 12 , respectivamente. Se recomienda que un proceso de mejora continua que involucre a todas las razas debe adoptarse mediante selección recurrente recíproca o modificaciones del ella.

\section{INTRODUCTION}

The Nigerian indigenous chicken has been described as small bodied slow growing, poor feed converters and poor meat animals (Nwosu and Asuquo, 1985). This is as a result of long-term natural selection for fitness in a harsh tropical and disease prevalent-environment. The local birds in Nigeria are a major source of raw materials from which sustainable protein supply can be developed within the nation, makes them a focal point for researchers as $90 \%$ of the 150 million chicken in Nigeria are the local varieties which contribute $90 \%$ and $72 \%$ of the egg and meat consumption (Nwanta et al., 2006). Series of reports on the characterisation of the local chickens revealed that they could be classified based on the occurrence of some major genes such as dwarf gene (Dw), naked neck gene (Na) and Frizzlin g gene (Fr) (Ikeobi et al., 1996, Adebambo et al., 1999). Large variations were also reported to exist among the birds in growth and egg laying performance (Peters, 2000). These findings have led to the conclusion that the indigenous birds have a great potential for meaningful genetic improvement for growth and therefore contribution to the protein dearth in the country (Omeje and Nwosu, 1983, Nwosu et al., 1985, Ikeobi et al., 1996, Adebambo et al., 1996, Peters, 2000). Monitoring changes in body weight and linear body parameters over time in closed breeding programs under controlled environment and management conditions, like in pedigree broiler breeding, is relevant to maximizing and tracking genetic progress during improvement programs (Banos et al., 2006), such body parameters have been studied and used as cross predictors especially for body weight which is a major productive trait determining market value among the Nigerian consumer (Adebambo et al., 1996, Adebambo et al., 1999, Adebambo et al., 2006).

Genetic progress can be attained either by selection or crossbreeding. Crossbreeding of the indigenous stock with exotic commercial birds will take advantage of artificial selection for productivity in the exotic birds and natural selection for hardiness in the indigenous birds. A good combining ability resulting from a choice of the best performing crossbred could lead to the production of birds that will be better in growth rate, efficiency of feed conversion and reproductive traits without sacrificing adaptation to the local environment, thereby resulting in reduced cost of production.

Test for good combining abilities is developed by generating a diallel cross, which is a set of possible combination between several genotypes and general populations and analysis of data from such crosses (Hayman, 1954). The general combining ability (GCA) is defined as the average performance of a line (strain or breed) in hybrid combination with other lines. The variation in GCA is due to additive genetic variance. The specific combining ability (SCA) refers to a cross produced by a pair of lines. It indicates cases where certain combinations (crosses) do relatively better or worse than would be expected on the basis of the average performance (GCA) of the two lines involved in producing that combination. Such crosses will therefore be selected for improvement or against as having individual cross advantage or disadvantage. The variation in SCA is due 
to non additive genetic variance; heterosis, dominance, over-dominance and epistasis, (Singh and Kumar, 1994).

The aim of this research was to study general and specific combining abilities existing in growth of pure and crossbred meat type chickens produced from four parental populations: Giriraja(G), Anak(A), Nigerian improved indigenous poultry chicken, Alpha (B) and the Local (N) as a preliminary broiler lines evaluation prior to selection in a national broiler improvement program.

\section{MATERIAL AND METHODS}

The experimental birds comprise of 5191 chicks produced from a combination of four breeds of chickens maintained at the Poultry Breeding Unit of the University Teaching and Research farm, University of Agriculture, Alabata road, Abeokuta, Nigeria; latitude $7^{\circ} 10^{\prime} \mathrm{N}$ and longitude $3^{\circ} 2^{\prime} \mathrm{E}$. The area has a tropical climate with a mean annual rainfall of about $1037 \mathrm{~mm}$. The mean monthly ambient temperature ranges from $28^{\circ} \mathrm{C}$ in December to $36^{\circ} \mathrm{C}$ in February with a yearly average of $34^{\circ} \mathrm{C}$. Relative humidity ranges from $60 \%$ in January to $94 \%$ in August with a yearly average of about $82 \%$. The vegetation represents an inter-phase between the tropical rainforest and the derived savannah. The chicken breeds include 45 Anak Titan: Israeli type commercial broiler (A), 58 Giriraja: Indian type dual purpose chicken (G), 75 Nigerian normal indigenous chicken (N), 61 Alpha: Nigerian developed improved indigenous for higher egg production (B) as diallel crosses, that is, both straight and reciprocal crosses generated over 2 year period 20062008. Eggs were collected daily for ten days from the breeder chickens maintained in battry cages with a period of one-week break between mating cocks. All the eggs were pedigreed before incubation. Hatched chicks from each strain or genotype were properly identified and wing tagged. All necessary vaccination and medication were supplied as at when due. Breeders were fed on a diet containing $11.704 \mathrm{MJ} / \mathrm{kg}$ metabolizable energy and $16 \%$ crude protein. The chicks were fed ad libitum on a broiler starter diet that supplied 23\% crude protein and $12.122 \mathrm{MJ} / \mathrm{kg}$ metabolizable energy from 0 to 4 weeks of age. Thereafter, they were fed on a broiler finisher diet that supplied $20.5 \%$ crude protein and $12.958 \mathrm{MJ} / \mathrm{kg}$ metabolizable energy from 5-12 weeks. Clean water was supplied ad libitum throughout the experimental period.

The chicks were wing-tagged along sire lines and weighed using a $0.01 \mathrm{~kg}$ sensitive scale. The skeletal dimensions were taken on weekly basis till the chicks reached 12 weeks of age. The birds were reared together, but differences in the parameters due to sex, age, season and other factors were noted. Parameters measured on weekly basis for 12 weeks were:

Body weight (BW): This was measured with the use of a weighing scale.

Tape rule was used in measuring the following linear body parameters:

Breast girth (BG): This was taken as the circumference of the breast around the deepest region of the breast.

Tibia length (TL): This was measured from the junction of tibia and femur to the junction of the tibia and metatarsus.

Analyses of variance of growth traits. A mixed model was set up to test effects of sire genotype, dam genotype, sex, age and season using the general linear models procedure of the Statistical Analysis System program (SAS, 1999). Sires and dams which were all represented in all the seasons were considered random effects with dams nested within sires. Sex, age and season were fixed effects. The same program was used to correct for effects of batch, sex and season by covariant relationship. Preliminary analyses show that interaction of season and sex were not significant and therefore was expunged from the analysis. The following model was used for weekly ana- 
lysis of all growth traits.

$\begin{aligned} Y_{i j k l} & =\mu+S_{i}+D_{j}+X_{k}+E_{l}+S D_{i j}+S X_{i k}+S E_{i l}+D X_{j k}+D E_{j l} \\ & +\varepsilon_{i j k l m n}\end{aligned}$

Where,

$Y_{\mathrm{ijkl}}=$ observed value of dependent variable;

$\mu=$ overall mean;

$\mathrm{S}_{\mathrm{i}}=$ effect due to $\mathrm{i}^{\text {th }}$ sire ( $\mathrm{i}=$ Anak titan, Giriraja, Local, Alpha);

$D_{j}=$ effect due to $j^{\text {th }}$ dam ( $j=$ Anak titan, Giriraja, Local, Alpha);

$X_{k}=$ effect due to $k^{\text {th }} \operatorname{sex}(k=$ male, female);

$E_{1}=$ effect due to $I^{\text {th }}$ season $(l=1,2,3,4)$;

$\mathrm{SD}_{\mathrm{ij}}=$ effect of the interaction of sire and dam genotype;

$\mathrm{SX}_{\mathrm{ik}}=$ effect of interaction of sire genotype and sex; $\mathrm{SE}_{\mathrm{il}}=$ effect of interaction of sire genotype and season;

$D X_{j k}=$ effect of interaction of dam genotype and sex;

$D E_{\mathrm{jl}}=$ effect of interaction of dam genotype and season;

$\varepsilon_{\mathrm{ijklmn}}=$ random residual error normally distributed with zero mean variance $\delta^{2}$.

Diallel analysis. In order to estimate general and specific combining abilities and specific combining ability, a diallel analysis was set up after adjusting for effects of batch, sex and season according to the method of Hayman (1954) using Genstat (1996) and Dial98 package (Ukai, 2002).

A diallel table was set up as follows:

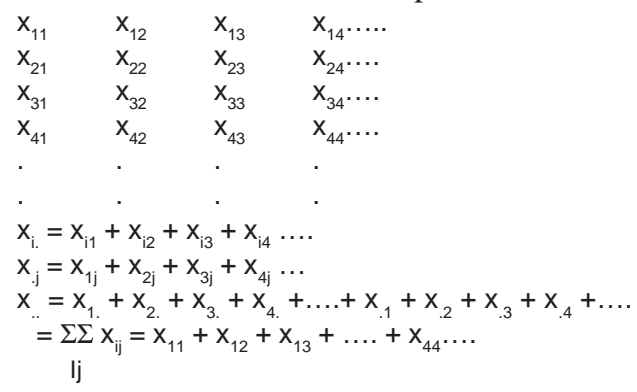

The following model was used:

$\mathrm{Y}_{\mathrm{rs}}=\mu+\mathrm{j}_{\mathrm{r}}+\mathrm{j}_{\mathrm{s}}+\mathrm{j}_{\mathrm{rs}}+\mathrm{k}_{\mathrm{r}}-\mathrm{k}_{\mathrm{s}}+\mathrm{k}_{\mathrm{rs}}$

Where,

$\mu=$ grand mean;

$\mathrm{j}_{\mathrm{r}}=$ mean deviation from the grand mean due to $\mathrm{r}^{\text {th }}$ parent;

$\mathrm{j}_{\mathrm{s}}=$ mean deviation from the grand mean due to $\mathrm{s}^{\text {th }}$ parent;

$\mathrm{j}_{\mathrm{rs}}=$ remaining discrepancies in the $\mathrm{rs}^{\text {th }}$ reciprocal sum;

$k_{r}=$ differences between the effect of the $r^{\text {th }}$ parental line used as male parent and as female parent;

$k_{s}=$ differences between the effect of the $s^{\text {th }}$ parental line used as male parent and as female parent;

$\mathrm{k}_{\mathrm{rs}}=$ remaining discrepancies in the $\mathrm{rs}^{\text {th }}$ reciprocal difference.

An extension of the model by fitting constants for dominance difference between parental mean and progeny mean and for deviation from this due to specific parents can be made.

The constant $\mathrm{j}_{\mathrm{rs}}$ can be subdivided into three constants:

$\mathrm{I}=$ mean dominance deviation (b1);

$\mathrm{I}_{\mathrm{r}}=$ further dominance deviation due to $\mathrm{r}^{\text {th }}$ parent (b2);

$\mathrm{I}_{\mathrm{rs}}=$ remaining discrepancy in the $\mathrm{rs}^{\text {th }}$ reciprocal sum (b3).

The extended statistical model was of the following form:

$Y_{r s}=\mu+j_{r}+j_{s}+I+I_{r}+I_{s}+k_{r}-k_{s}+k_{r s}$

Test of significance for overall differences among various classes of effects was done with error mean square $\left(M_{e}{ }^{\prime}\right)$.

The various effects were estimated as follows:

$\mu=1 / p^{2} X$.

where,

$\mu=$ population mean;

$\mathrm{P}=$ number of lines for crossing;

$\mathrm{X}=$ grand total.

General combining ability effects of crosses was calculated as:

$g_{i}=1 / 2 p\left(X_{i}+X_{i .}\right)-1 / p^{2} X$

Archivos de zootecnia vol. 60, núm. 232, p. 956. 
Specific combining ability effects of crosses was calculated as:

$s_{i j}=1 / 2\left(X_{i j}+X_{j i}\right)-1 / 2 p\left(X_{i .}+X_{i j}+X_{j .}+X_{i j}\right)+1 / 2 p X$.

\section{RESULTSANDDISCUSSION}

\section{SIREEFFECT ONGROWTHTRAITS}

The results of the present study showed that sire and dam genotypes had significant $(\mathrm{p}<0.05)$ effects on growth traits (table $\mathbf{I})$. The exotic breeds performed better for body weight, with Anak Titan having the highest body weight for both dam and sire genotypes, while the normal indigenous and Alpha improved indigenous performed better in the linear body parameters. The exotics have been selected for improved growth rate, while the indigenous are generally selected for traits that will aid in fitness in the environment, like wide wing span for flight from predators and long shank lengths for speed. These are all adaptive traits for specific environment. This was supported by Deeb and Lamont (2002) who reported shank length measurement in poultry though characterized by high heritability, when long relative to their weight are considered unfit and a source of leg problems in heavy-bodied chickens. Therefore meat-type birds have been successfully selected for proportionally shorter shanks for many generations. This is also the case for other linear body parameters. Effects of sex (table II) on the traits was generally not signicant $(\mathrm{p}>0.05)$

Table I. Means of growth traits as affected by sire and dam genotype at weeks 1, 4, 8 and 12 for four meat type chickens. (Medias de los caracteres de crecimiento afectados por los genotipos del macho y de la hembra para cuatro tipos de pollos de carne, en las semanas 1, 4, 8 y 12).

\begin{tabular}{|c|c|c|c|c|c|c|c|}
\hline $\begin{array}{l}\text { Age } \\
\text { Effects }\end{array}$ & $\mathrm{N}$ & $\begin{array}{l}\text { Body weight } \\
\text { (g) }\end{array}$ & $\begin{array}{l}\text { Sire } \\
\text { Breast girth } \\
\quad(\mathrm{cm})\end{array}$ & $\begin{array}{l}\text { Tibia length } \\
\text { (cm) }\end{array}$ & $\begin{array}{l}\text { Body weight } \\
\text { (g) }\end{array}$ & $\begin{array}{l}\text { Dam } \\
\text { Breast girth } \\
\text { (cm) }\end{array}$ & $\begin{array}{l}\text { Tibia length } \\
(\mathrm{cm})\end{array}$ \\
\hline \multicolumn{8}{|l|}{1 week } \\
\hline Anak & 1956 & $40.21 \pm 0.66^{a}$ & $6.10 \pm 0.13$ & $2.99 \pm 0.05^{c}$ & $38.45 \pm 0.74$ & $5.60 \pm 0.12^{b}$ & $3.24 \pm 0.17^{\mathrm{b}}$ \\
\hline Giriraja & 1804 & $35.28 \pm 1.86^{b}$ & $6.51 \pm 0.25$ & $2.95 \pm 0.04^{c}$ & $34.33 \pm 1.01$ & $6.57 \pm 0.18^{a}$ & $3.20 \pm 0.08^{b}$ \\
\hline Normal & 1040 & $30.38 \pm 0.8^{c}$ & $6.13 \pm 0.18$ & $4.58 \pm 0.24^{\mathrm{a}}$ & $29.93 \pm 0.94$ & $6.46 \pm 0.14^{\mathrm{a}}$ & $3.87 \pm 0.17^{a}$ \\
\hline Alpha & 391 & $33.0 \pm 0.51^{b}$ & $6.6 \pm 0.22$ & $3.97 \pm 0.23^{b}$ & $33.02 \pm 0.97$ & $6.83 \pm 0.37^{a}$ & $3.63 \pm 0.19^{a b}$ \\
\hline \multicolumn{8}{|l|}{4 weeks } \\
\hline Anak & 1675 & $285.73 \pm 8.69^{a}$ & $10.52 \pm 0.16^{b}$ & $5.31 \pm 0.12^{b}$ & $280.5 \pm 7.86^{a}$ & $10.20 \pm 0.15^{c}$ & $5.69 \pm 0.22$ \\
\hline Giriraja & 1697 & $265.18 \pm 9.92^{\mathrm{b}}$ & $10.48 \pm 0.15^{b}$ & $5.42 \pm 0.11^{b}$ & $218.91 \pm 6.19^{b}$ & $11.68 \pm 0.25^{\mathrm{a}}$ & $6.0 \pm 0.15$ \\
\hline Normal & 935 & $179.75 \pm 6.53^{c}$ & $11.0 \pm 0.22^{\mathrm{a}}$ & $6.81 \pm 0.19^{a}$ & $177.05 \pm 8.41^{\mathrm{c}}$ & $10.78 \pm 0.18^{\mathrm{b}}$ & $6.15 \pm 0.15$ \\
\hline Alpha & 352 & $205.90 \pm 7.43^{d}$ & $11.15 \pm 0.36^{\mathrm{a}}$ & $7.02 \pm 0.31^{\mathrm{a}}$ & $200.92 \pm 13.78^{b}$ & $10.46 \pm 0.18^{b c}$ & $6.0 \pm 0.22$ \\
\hline \multicolumn{8}{|l|}{8 weeks } \\
\hline Anak & 1405 & $791.45 \pm 19.19^{a}$ & $15.14 \pm 0.23^{b}$ & $6.09 \pm 0.12^{\mathrm{ab}}$ & $707.73 \pm 16.54^{a}$ & $15.61 \pm 0.25^{b}$ & $8.51 \pm 0.27^{b}$ \\
\hline Giriraja & 1529 & $636.53 \pm 18.28^{b}$ & $16.16 \pm 0.25^{a}$ & $6.3 \pm 0.16^{a}$ & $665.45 \pm 18.08^{b}$ & $16.82 \pm 0.3^{a}$ & $9.33 \pm 0.23^{a}$ \\
\hline Normal & 935 & $484.79 \pm 12.07^{c}$ & $16.63 \pm 0.3^{a}$ & $6.51 \pm 0.2^{b}$ & $473.14 \pm 14.72^{c}$ & $16.0 \pm 0.27^{\mathrm{b}}$ & $9.63 \pm 0.23^{a}$ \\
\hline Alpha & 305 & $594.89 \pm 17.72^{b}$ & $16.74 \pm 0.51^{\mathrm{a}}$ & $6.2 \pm 0.24^{\mathrm{ab}}$ & $517.85 \pm 25.06^{b}$ & $15.75 \pm 0.25^{\mathrm{b}}$ & $9.27 \pm 0.31^{\mathrm{a}}$ \\
\hline \multicolumn{8}{|l|}{12 weeks } \\
\hline Anak & 760 & $1311.85 \pm 54.47^{a}$ & $19.51 \pm 0.33^{b}$ & $11.68 \pm 0.25$ & $1135.93 \pm 35.67^{a}$ & $19.62 \pm 0.38^{b}$ & $11.33 \pm 0.33$ \\
\hline Giriraja & 1063 & $1027.5 \pm 33.18^{b}$ & $19.82 \pm 0.24^{a b}$ & $11.8 \pm 0.27$ & $1061.35 \pm 41.94^{a}$ & $20.92 \pm 0.29^{a}$ & $12.53 \pm 0.31$ \\
\hline Normal & 798 & $809.46 \pm 20.14^{c}$ & $20.36 \pm 0.31^{a}$ & $13.07 \pm 0.34$ & $800.84 \pm 25.2^{c}$ & $19.51 \pm 0.29^{b}$ & $12.41 \pm 0.25$ \\
\hline Alpha & 211 & $953.38 \pm 35.38^{b}$ & $19.62 \pm 0.49^{a b}$ & $12.68 \pm 0.38$ & $901.7 \pm 47.11^{\mathrm{b}}$ & $19.49 \pm 0.28^{\mathrm{b}}$ & $12.07 \pm 0.37$ \\
\hline
\end{tabular}

Means in the same column and week with different superscripts are significantly different $(p<0.05)$. 


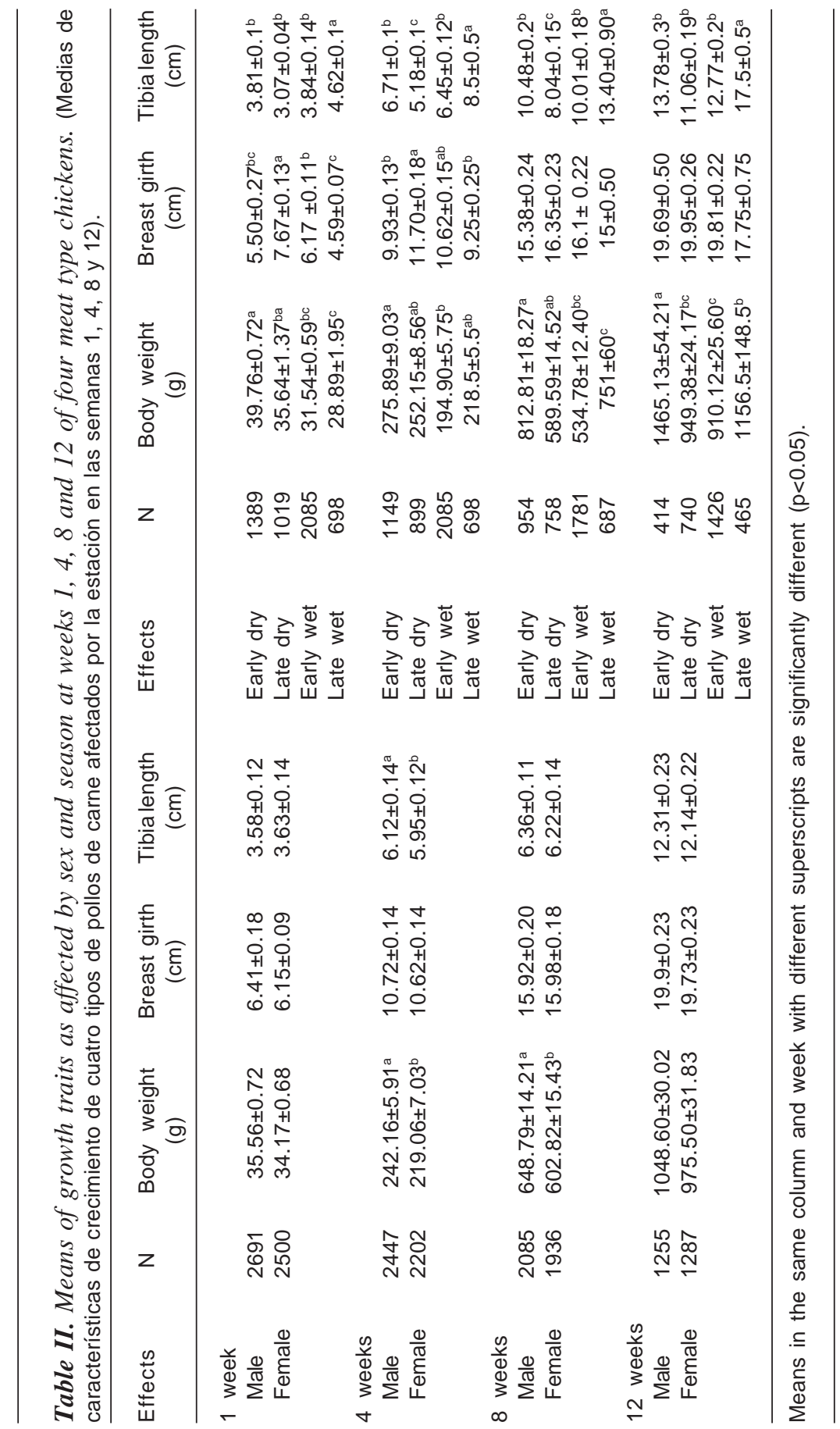




\section{COMBINING ABILITIES OF GROWTH TRAITS AMONG MEAT TYPE CHICKENS}

throughout the study with the exception of BW at weeks 4 and 8 and TL at week 4 most likely due to non establishment of sexual dimorphism in the young birds. Season had significant $(p<0.05)$ effects on the growth of the birds with exception of BG at weeks 8 and 12. BW was highest at the early dry season through out the experiment.

\section{GCA ON BODY WEIGHT}

Table III shows that additive effects were generally more important than dominance in determining body weight. This is corroborated by the higher values of GCA than SCA in table VI. The result is supported by the work of Mekki et al. (2005) who found general combining ability estimates more important and of higher value than specific combining ability in determining body weight at maturity of exotic cockerels. This indicates that selection will be a better tool for improvement in this trait. Mekki et al. (2005) also found that the exotic commercial birds had higher GCA values than the indigenous. This means, the exotics had lower gene variation for body weight. This is in line with the result derived here, as the Anak Titan had the highest GCA (tableIII) resulting from high selection pressure, which reduced variation. On the other hand Giriraja and Alpha (improved indigenous) show generally negative GCA, which indicate the inferior performance of these breeds in their hybrid combination for body weight. The Normal indigenous shows low but positive GCA, indicating good hybrid abilities and higher gene variations for BW; indicative of room for improvement. Anak Titan and Normal indigenous will be good for an improvement program for body weight.

\section{GCA ON LINEAR BODY MEASUREMENTS}

Table IV shows that dominance was more important in determining BG as it had a higher value and more significant $(p<0.05)$ than additive variance indicative of the need to improve this trait using cross breeding.

Table III. Hayman (1954) ANOVA for body weight at 1, 4, 8 and 12 weeks old. (ANOVA (Hayman, 1954) para el peso corporal en las semanas 1, 4, 8 y 12).

\begin{tabular}{llllll}
\hline Source & DF & & \multicolumn{3}{c}{ Means square } \\
& & 1 week & 4 weeks & 8 weeks & 12 weeks \\
\hline Rep & 4 & $10.8^{\text {ns }}$ & $6299.4^{\star}$ & $20872.5^{\text {ns }}$ & $96810.0^{*}$ \\
A & 3 & $374.7^{\text {** }}$ & $83354.2^{\star *}$ & $260748.3^{\star *}$ & $593180.0^{\star *}$ \\
B & 6 & $13.8^{\text {ns }}$ & $5440.1^{*}$ & $27678.0^{*}$ & $165043.4^{\star *}$ \\
B1 & 1 & $4.9^{\text {ns }}$ & $1338.1^{\text {ns }}$ & $0.3^{\text {ns }}$ & 15873.9 \\
B2 & 3 & $4.0^{\text {ns }}$ & $8158.1^{*}$ & $50127.4^{\star *}$ & $315439.3^{\star *}$ \\
B3 & 2 & $32.8^{\text {ns }}$ & $3414.0^{\text {ns }}$ & $7842.6^{\text {ns }}$ & $14034.2^{\text {ns }}$ \\
C & 3 & $25.1^{\text {ns }}$ & $6005.5^{\text {ns }}$ & $3630.1^{\text {ns }}$ & $41075.7^{\text {ns }}$ \\
D & 3 & $8.14^{\text {ns }}$ & $1829.3^{\text {ns }}$ & $7896.7^{\text {ns }}$ & $10148.8^{\text {ns }}$ \\
Error & 60 & 18.0 & 2357.4 & 10129.6 & 35668.0 \\
Total & 79 & & & & \\
\hline
\end{tabular}

DF: degrees of freedon.

Rep: replication; A: variation between the mean effects of each parental lines; $B$ : variation in the reciprocal sums not ascribable to (A); B1: Mean dominance deviation; B2: further dominance deviation due to the rth parent; B3: remaining discrepancy in the rsth reciprocal sum; C: Average maternal effects of each parental line; D: Variation in the reciprocal differences not ascribable to (C); ${ }^{*} p<0.05,{ }^{* *} p<0.01$, ${ }^{* \star \star} p<0.001$, ${ }^{n}$ not significant. 
Table IV. Hayman (1954) ANOVA for linear body measurement at 1, 4, 8 and 12 weeks old. (ANOVA (Hayman, 1954) para medida corporal lineal en las semanas 1, 4, 8 y 12).

\begin{tabular}{|c|c|c|c|c|c|c|c|c|c|}
\hline \multirow{3}{*}{$\begin{array}{l}\text { Source } \\
\text { Age (wks) }\end{array}$} & \multirow[t]{3}{*}{ DF } & \multicolumn{8}{|c|}{ Mean square } \\
\hline & & \multicolumn{4}{|c|}{ Breast girth } & \multicolumn{4}{|c|}{ Tibia length } \\
\hline & & 1 & 4 & 8 & 12 & 1 & 4 & 8 & 12 \\
\hline Rep & 4 & $0.58^{\text {ns }}$ & $0.61^{\text {ns }}$ & $6.45^{\star *}$ & $3.80^{*}$ & $0.17^{\mathrm{ns}}$ & $1.43^{\text {ns }}$ & $2.68^{\text {ns }}$ & $8.28^{* *}$ \\
\hline A & 3 & $2.30^{*}$ & $0.66^{\mathrm{ns}}$ & $6.40^{\star *}$ & $2.01^{\mathrm{ns}}$ & $11.59 * *$ & $8.93^{\star \star}$ & $15.21^{\star *}$ & $13.76^{\star \star}$ \\
\hline B & 6 & $11.38^{\star \star}$ & $14.47^{\star \star}$ & $22.58^{\star \star}$ & $11.16^{\star \star}$ & $9.24^{\star \star}$ & $10.67^{\star *}$ & $13.00^{* *}$ & $3.51^{*}$ \\
\hline B1 & 1 & $5.91^{\star \star}$ & $2.63^{\text {ns }}$ & $0.14^{\mathrm{ns}}$ & $10.09 * \star$ & $0.22^{\text {ns }}$ & $1.40^{\mathrm{ns}}$ & $6.59 *$ & $5.73^{\star}$ \\
\hline B2 & 3 & $9.12^{\star *}$ & $10.02^{* *}$ & $12.56^{\star *}$ & $3.06^{\text {ns }}$ & $6.76^{\star *}$ & 6.20 ** & $12.58^{\star *}$ & $3.07^{\mathrm{ns}}$ \\
\hline B3 & 2 & $17.50^{\star \star}$ & $27.06^{* *}$ & $48.83^{\star *}$ & $23.85^{\star \star}$ & $17.48^{* *}$ & $22.02^{* *}$ & $16.85^{\star \star}$ & $3.07^{\text {ns }}$ \\
\hline C & 3 & $4.26^{\star \star}$ & $1.95^{\mathrm{ns}}$ & $1.20^{\mathrm{ns}}$ & $4.79^{\star}$ & $3.93^{\star *}$ & $5.07^{* *}$ & $4.33^{\star}$ & $6.09 * *$ \\
\hline D & 3 & $3.69 * *$ & $0.59^{\text {ns }}$ & $0.19^{\text {ns }}$ & $2.19^{\text {ns }}$ & $0.25^{\mathrm{ns}}$ & $0.70^{\text {ns }}$ & $0.44^{\mathrm{ns}}$ & $1.13^{\text {ns }}$ \\
\hline Error & 60 & 0.75 & 1.71 & 1.33 & 1.21 & 0.27 & 0.68 & 1.31 & 1.43 \\
\hline Total & 79 & & & & & & & & \\
\hline
\end{tabular}

DF: degrees of freedon.

Rep: replication; A: variation between the mean effects of each parental lines; $B$ : variation in the reciprocal sums not ascribable to (A); B1: Mean dominance deviation; B2: further dominance deviation due to the rth parent; B3: remaining discrepancy in the rsth reciprocal sum; C: Average maternal effects of each parental line; D: Variation in the reciprocal differences not ascribable to (C); ${ }^{*} p<0.05,{ }^{* *} p<0.01$, ${ }^{* * \star} p<0.001,{ }^{n s}$ not significant.

On the other hand both dominance and additive variation were generally significant in determining TL, showing both selection and cross breeding as tool to increase for this trait. The GCA results (tables VI and VII) showed generally low values corroborating the need to utilize cross breeding to improve the traits based on higher non

Table V. Combining abilities for body weight at 1, 4, 8 and 12 weeks old. (Capacidad de combinación para la peso corporal en las semanas $1,4,8$ y 12).

\begin{tabular}{lccccc}
\hline Parameters & $N$ & 1 week & 4 weeks & 8 weeks & 12 weeks \\
\hline \multicolumn{7}{c}{ General combining abilities (GCA) } & & & & \\
G-Anak (a) & 1956 & $19.49 \pm 0.42$ & $288.54 \pm 7.52$ & $458.78 \pm 12.15$ & $769.30 \pm 4.80$ \\
G-Giriraja (g) & 1804 & $-3.75 \pm 0.37$ & $-162.94 \pm 5.94$ & $-246.71 \pm 9.10$ & $-377.55 \pm 16.70$ \\
G-normal (n) & 1040 & $-0.81 \pm 0.65$ & $76.13 \pm 4.95$ & $206.30 \pm 15.28$ & $381.60 \pm 27.20$ \\
G-alpha (b) & 391 & $-14.94 \pm 0.75$ & $-201.72 \pm 11.82$ & $-418.37 \pm 18.59$ & $-773.35 \pm 17.93$ \\
Specific combining abilities (SCA) & & & & \\
S-ag & 824 & $-0.40 \pm 0.51$ & $51.59 \pm 14.11$ & $-70.81 \pm 29.21$ & $-301.11 \pm 51.11$ \\
S-an & 384 & $9.70 \pm 1.26$ & $-84.83 \pm 5.65$ & $8.62 \pm 15.64$ & $167.28 \pm 68.35$ \\
S-ab & 442 & $-7.38 \pm 0.68$ & $-85.55 \pm 11.60$ & $-216.92 \pm 6.63$ & $-407.47 \pm 19.94$ \\
S-gn & 397 & $-0.94 \pm 0.72$ & $152.40 \pm 13.54$ & $390.69 \pm 31.68$ & $634.82 \pm 37.93$ \\
S-gb & 687 & $5.01 \pm 0.15$ & $-88.58 \pm 2.00$ & $30.99 \pm 11.05$ & $-127.08 \pm 9.65$ \\
S-nb & 403 & $-4.94 \pm 0.82$ & $-15.87 \pm 22.19$ & $-143.96 \pm 31.17$ & $-188.43 \pm 39.45$ \\
\hline
\end{tabular}

G: general combining ability; S: specific combining ability.

Archivos de zootecnia vol. 60, núm. 232, p. 960. 
additive gene effects. This will most likely be as a result of non intense selection for linear body parameters as seen in body weight among the breeds. This observation was also noted by Deeb and Lamont (2002) who reported high phenotypic variance for a trait like percent drum stick (tibia length) as a result of non specific direct selection for the trait.

\section{SCAON BODY WEIGHT}

The effect of SCA on body weight, which involves dominance, over dominance and epistasis, was not as significant as GCA (tables III and V). This is in agreement with the results obtained by Wearden et al. (1965) and Singh et al. (1983) who pointed out that in traits with high heritability, specific combining ability effects upon individual performance were relatively higher than its influence on family performance. This non-additive hereditary interaction may be an important source of variance among individuals without major influence upon family performance.

\section{SCAON LINEAR MEASUREMENTS}

Specific combining ability was a signi- ficant source of variability (table IV) and also showed higher values than GCA (tables VI and VII) among the cross-bred groups for linear body measurements during all age intervals. This indicates importance of nonadditive genetic component on these traits during the periods of observation. SCA constants estimates for different breeds in tables VI and VII showed that cross between Giriraja and Alpha exhibit higher individual performance for BG and TL. This further affirms that improvement program using this cross would be appropriate when the goal is to promote faster growth in these traits.

\section{CONCLUSIONS}

Combining abilities show that the chicken breeds all have different breed advantages for the traits observed in this study. It is therefore recommended that an improvement program that involves exploiting the trait advantages of the breeds should be used. Development of a broiler line should involve Anak Titan as a sire line due to good general combining ability for BW, while individual performance of the

Table VI. Combining abilities for breast girth at 1, 4, 8 and 12 weeks old. (Capacidad de combinación para la contorno de pechuga en las semanas 1, 4, 8 y 12).

\begin{tabular}{lccccc}
\hline Parameters & $N$ & 1 week & 4 weeks & 8 weeks & 12 weeks \\
\hline \multicolumn{2}{l}{ General combining abilities (GCA) } & & & & \\
G-Anak (a) & 1956 & $-1.78 \pm 0.10$ & $-0.90 \pm 0.13$ & $-2.40 \pm 0.14$ & $-1.67 \pm 0.16$ \\
G-Giriraja (g) & 1804 & $1.07 \pm 0.09$ & $-0.02 \pm 0.09$ & $0.05 \pm 0.15$ & $0.05 \pm 0.10$ \\
G-normal (n) & 1040 & $0.36 \pm 0.10$ & $0.45 \pm 0.11$ & $0.02 \pm 0.14$ & $0.47 \pm 0.14$ \\
G-alpha (b) & 391 & $0.36 \pm 0.10$ & $0.47 \pm 0.15$ & $2.33 \pm 0.13$ & $1.16 \pm 0.07$ \\
Specific combining abilities (SCA) & & & & \\
S-ag & 824 & $3.44 \pm 0.41$ & $2.93 \pm 0.55$ & $1.42 \pm 0.48$ & $-1.93 \pm 0.43$ \\
S-an & 384 & $4.20 \pm 0.19$ & $5.67 \pm 0.34$ & $5.39 \pm 0.35$ & $5.82 \pm 0.28$ \\
S-ab & 442 & $-2.20 \pm 0.17$ & $-2.98 \pm 0.31$ & $-4.87 \pm 0.12$ & $-4.69 \pm 0.22$ \\
S-gn & 397 & $-4.45 \pm 0.18$ & $-5.84 \pm 0.29$ & $-8.60 \pm 0.23$ & $-8.00 \pm 0.17$ \\
S-gb & 687 & $7.43 \pm 0.11$ & $8.21 \pm 0.16$ & $11.82 \pm 0.22$ & $5.90 \pm 0.29$ \\
S-nb & 403 & $-3.09 \pm 0.26$ & $-4.85 \pm 0.10$ & $-4.70 \pm 0.35$ & $-3.88 \pm 0.18$ \\
\hline
\end{tabular}

G: general combining ability; S: specific combining ability. 
Table VII. Combining abilities for tibia length at 1, 4, 8 and 12 weeks old. (Capacidad de combina-ción para la longitud de la tibia en las semanas 1, 4, 8 y 12).

\begin{tabular}{lccccc}
\hline Parameters & $\mathrm{N}$ & 1 week & 4 weeks & 8 weeks & 12 weeks \\
\hline General combining abilities (GCA) & & & & \\
G-Anak (a) & 1956 & $-1.55 \pm 0.03$ & $-2.19 \pm 0.06$ & $-3.62 \pm 0.08$ & $-3.81 \pm 0.14$ \\
G-Giriraja (g) & 1804 & $1.61 \pm 0.08$ & $0.57 \pm 0.21$ & $2.12 \pm 0.08$ & $1.89 \pm 0.07$ \\
G-normal (n) & 1040 & $-2.91 \pm 0.07$ & $-1.50 \pm 0.16$ & $-1.46 \pm 0.26$ & $-0.65 \pm 0.21$ \\
G-alpha (b) & 391 & $2.85 \pm 0.12$ & $3.12 \pm 0.14$ & $2.96 \pm 0.16$ & $2.56 \pm 0.16$ \\
Specific combining abilities (SCA) & & & & \\
S-ag & 824 & $-2.51 \pm 0.09$ & $-3.75 \pm 0.25$ & $-7.79 \pm 0.13$ & $-5.38 \pm 0.24$ \\
S-an & 384 & $1.51 \pm 0.05$ & $3.01 \pm 0.17$ & $0.61 \pm 0.12$ & $0.85 \pm 0.21$ \\
S-ab & 442 & $-3.24 \pm 0.10$ & $-1.77 \pm 0.10$ & $-2.68 \pm 0.13$ & $0.24 \pm 0.26$ \\
S-gn & 397 & $-4.04 \pm 0.08$ & $-2.46 \pm 0.28$ & $-1.55 \pm 0.45$ & $-0.52 \pm 0.51$ \\
S-gb & 687 & $8.50 \pm 0.10$ & $9.68 \pm 0.10$ & $7.92 \pm 0.34$ & $0.86 \pm 0.30$ \\
S-nb & 403 & $-0.72 \pm 0.20$ & $-2.32 \pm 0.26$ & $-1.49 \pm 0.28$ & $-0.47 \pm 0.19$ \\
\hline
\end{tabular}

G: general combining ability; S: specific combining ability.

Giriraja and Alpha should be utilized in improving for BG and TL. This will aid in development of lines that are each selected for a set of traits. The production animals will be hybrids in which all the desired traits are combined with a full exploitation of

\section{REFERENCES}

Adebambo, O.A., Ikeobi, C.O.N., Ozoje, M.O., Adenowo, J.A. and Osinowo, O.A. 1996. Variations in qualitative traits and their effects on the performance of local ducks and turkeys. Nig. J. Genet., 11: 20-32.

Adebambo, O.A., Ikeobi, C.O.N., Ozoje, M.O. and Adenowo, J.A. 1999. Color variations and performance characteristics of the indigenous chicken of South Western Nigeria. Nig. J. Anim. Prod., 26: 15-22.

Adebambo, A.O., Ozoje, M.O., Abiola, S.S. and Adebambo, F. 2006. Analysis of the growth gurves of Indian and Nigerian chicken ecotypes In the humid tropics. ASSET Journal series A, 6: 103-110.

Banos,G., Avendano, S. and Olori, V. 2006. Time dependent genetic parameters for broiler chicken body weight measured in selection and commercial environments. $8^{\text {th }}$ World Congress on Genetics Applied to Livestock Production, heterosis. The reciprocal recurrent selection or modifications of it will exploit the entire genetic variance, both additive (general combining ability) and non-additive (specific combining ability) due to heterosis, dominance, over-dominance and epistasis.

August 13-18. Belo Horizonte, MG. Brasil.

Deeb, N. and Lamont, S.J. 2002. Genetic architecture of growth and body composition in unique chicken populations. J. Hered., 93: 107118.

Genstat 5 Release 3. 1996. Reference manual. Genstat 5 Committee of the Statistics Department. Rothamsted Experimental Station. AFRC Institute of Arable Crops Research. Harpenden. Hertfordshire. 796 pp.

Hayman, B.I. 1954. The analysis of variance of diallel tables. Biometrics, 10: 235-244.

Ikeobi, C.O.N., Ebozoje, M.O., Adebambo, O.A., Adenowo, J.A. and Osinowo, O.A. 1996. Genetic differences in the performance of the local chicken in South Western Nigeria. Nig. J. Genet., 11: 55-60.

Mekki Dafaalla, M., Yousif Ibrahimm, A., Abdel Rahman, M.K., Wang, J.Y. and Musa, H.H. 2005. Growth performance of indigenous $x$ exotic

Archivos de zootecnia vol. 60, núm. 232, p. 962. 


\section{COMBINING ABILITIES OF GROWTH TRAITS AMONG MEAT TYPE CHICKENS}

crosses of chicken and evaluation of general and specific combining ability under Sudan condition. Int. J. Poult. Sci., 4: 468-471.

Nwanta, J.A., Umoh, J.U., Abdu, P.A., Agogi, I. and Alibalogun, J.K. 2006. Management of losses and Newcastle disease in rural poultry in Kaduna State. Nig. J. Anim. Prod., 33: 274-285.

Nwosu, C.C. and Asuquo, B.O. 1985. Body weight improvement in the local chicken. Proc. $10^{\text {th }}$ Annual Conf. Nigeria Society for Animal Production. March 24-28. Ile-Ife, Nigeria. pp. 23-29.

Nwosu, C.C., Gowen, F.A., Obioha, F.C., Akpan, I.A. and Onuora, G.I. 1985. Biometrical study of the conformation of the native chicken. Nig. J. Anim. Prod., 12: 141-146.

Omeje, S.S.I. and Nwosu, C.C. 1983. Egg production patterns in local chickens and their crosses in the short term. Nig. J. Anim. Prod., 10: 91-96.

Peters, S.O. 2000. Genetic variation in the reproductive performance of indigenous chicken and the growth rates of its pure and halfbred progeny. M. Sc. Thesis. Department of Animal Breeding and Genetics. University of Agriculture. Abeokuta. 120 pp.

SAS. 1999. Statistical Analysis System. Users guide. SAS Inst. Inc. Cary. North Carolina.

Singh, R.P. and Kumar, J. 1994. Biometrical methods in poultry breedings. Kalyani publishers. $240 \mathrm{pp}$.

Singh, Y.P., Singh, R.P. Chaudhary, R.V. and Vikram S. 1983. Diallel crossing for estimation of GCA, SCA, heterosis and other genetic effects of various traits in White Leghorn. Ind. Vet. J., 60: 384-389.

Ukai, Y. 2002. Genetic analysis of quantitative traits. Igaku Shuppan. Tokyo. (In Japanese).

Wearden, S.D.T. and Craig, J.V. 1965. Use of a full diallel cross to estimate general and specific combining ability in chickens. Poult. Sci., 44: 1043-1053. 